\title{
Legal Origins and Intersectoral Regulation of AEO Institution
}

\section{Tetyana Ostrikova*}

Ostrikova, T. (2022). Legal Origins and Intersectoral Regulation of AEO Institution. Lex Portus, 8(1), 49-65. https://doi.org/10.26886/2524-101X.8.1.2022.3

*PhD researcher, Department of Financial Law, Institute of Law, Taras Shevchenko National University of Kyiv (60, Volodymyrska St., Kyiv, Ukraine) https://orcid.org/0000-0002-7059-7565 (c) $\$\left(\begin{array}{l}\text { This work is licensed under a Creative Commons Attribution- } \\ \text { NonCommercialShareAlike } 4.0 \text { International License }\end{array}\right.$

\section{ABSTRACT}

The main elements of AEO institution initially emerged in legislations of different countries, which legal systems belong both to common law and civil law families. In addition, there was an inevitable variability towards the tasks being solved, from general supply chain security issues to a focus on countering terrorist threats. At the same time, the modern AEO standards formed both at the level of international organizations, like WCO and WTO, and the regional level, such as the EU and associated countries. Therefore, we argue that there are several promising approaches to analyzing the legal status of AEO, including the concept of 'legal origins' and the institutions' legal theories. They have a significant potential for explaining national differences in the implementation of the AEO institution, the specifics of the interaction of the norms of different branches of law in regulating the activities of the AEO, the methods, and methods of state administration of the AEO programs. Besides, the paper addresses the issue of intersectoral regulation of AEO institution, which embraces norms of several branches of law, including both public (administrative, tax and customs) 
law and private. Furthermore, the idea of delegation of competence and responsibilities towards granting supply chains security from state authorities to private entities (i.e. 'trusted traders') creates a shift in legal regulation where different internal rules and practices of private companies become essential to achieving the tasks assigned to AEO institution.

The keywords: AEO, institution, customs, security, supply chain, legal origins, trade facilitation.

\section{Introduction}

After the worldwide introduction of Authorized Economic Operator (AEO) made through WCO SAFE Framework of Standards to Secure and Facilitate Global Trade in June 2005, its legal status became another internationally recognized trade facilitation standard for customs legislation. However, the fact that we speak about specific conditions for doing business for private entities enhances the AEO status goes far beyond mere customs or administrative legal regulations. Due to Tweddle (2008), the aim of AEO introduction, besides improving customs to business relations, was to provide businesses with an internationally recognized quality mark, indicating that their role in the international supply chain is secure, and their customs controls and procedures are efficient and compliant. Such AEO 'quality mark' embraces two basics aspects:

- recognition that the company is reliable in the traditional financial and customs terms, and;

- assuring that the company's compliance with security and safety standards permits other companies to consider it as a 'secure' trader and thus a reliable trading partner.

These facts permit to assess the AEO legal institute as the 'intersectoral one incorporating legal norms both of public law (administrative, customs, tax legislation) and private law (specific regulations governing respective internal and external business processes of AEO). Hence, an intersectoral approach to studying AEO legal status is becoming more relevant for forming new knowledge and discoveries in the field. Such studies are often driven 
into specific doctrinal and regulatory frameworks, which directly impact the specifics of the conclusions made in such studies.

Moreover, the history of AEO's implementation shows that respective standards have been initially developed in a limited number of countries and later shared as standards through different international instruments, both binding (such as WTO Trade Facilitation Agreement) and non-binding (such as WCO SAFE Standards). Thus, for many jurisdictions, AEO institutions derived from the supranational level and in many respects may be significantly uncommon for national legal systems and practices. This points out a specific 'legal origin' of AEO institutions. The term 'legal origin' in this case is quite uneven, and however, it possesses significant explanation potential.

\section{Methodology}

This article discusses perspectives of approaching the status of AEO from standpoints of several theoretical concepts. Firstly, the paper investigates an explanation potential of the concept of 'legal origins' shown its effectiveness in comparative studies of legislation related to different aspects of economic activity. Secondly, it an institutional approach to the legal status of the AEO, which allows looking at the interaction of the legal norms of different industries and different methods of legal regulation concerning this phenomenon.

\section{The Legal Origin Concept and AEO Status}

The 'legal origins' concept initially emerged in the late 1990th within the frameworks of comparative economic and law research of financial development and protection of investors' rights that revealed significant differences between common law and civil law countries. Particularly, it was documented empirically that legal rules protecting investors vary systematically among legal traditions or origins, with the laws of common law countries (originating in English law) being more protective of outside investors than the 
laws of civil law (originating in Roman law) and particularly French civil law countries (La Porta et al., 2008, p. 285-286). In addition, a legal origin may proxy for institutions that are not fundamentally related to the legal system (Beck et al., 2003). Furthermore, an extensive body of research in economics and law suggests that the legal model a country follows - known as its 'legal origins' - has profound long-run effects on many economic, political, and social outcomes (Bradford et al., 2021).

The fact that specific legal rules and regulations differ systematically across countries depending upon the typology of legal systems eventually led to four basic conclusions:

- legal rules and regulations differ systematically across countries, and these differences can be measured and quantified;

- these differences in legal rules and regulations are accounted for to a significant extent by legal origins;

- the basic historical divergence in the styles of legal traditions the policy-implementing focus of civil law versus the marketsupporting focus of common law- explains well why legal rules differ;

- the measured differences in legal rules matter for economic and social outcomes (La Porta et al., 2008, p. 326).

In these terms, a 'legal origins' indicates a well-established substantive characteristic of a particular legal phenomenon. Pointing to the legal status of the AEO, we thus wanted to emphasize the exclusivity of the relevant characteristics of the studied legal phenomenon. Furthermore, concerning the AEO, the 'legal origins' category can be utilized in two aspects. Firstly, it is the issue of legal origins of respective standards and regulations; secondly, it is the influence of national legal traditions of given countries upon the peculiarities of AEO implementation at the national level.

Respective theories connect legal origins to the financial outcomes of businesses, specifying the latter influencing through political and adaptability peculiarities of a given legal system. In terms of political 
'channel,' peculiarities of legal traditions may differ in terms of the priority they give to private property rights relative to the rights of the State, which is essential for economic development. In terms of adaptability 'channel', legal traditions, due to their responsiveness to changing socioeconomic conditions, thus inflexible legal traditions produce gaps between legal capabilities and commercial needs, whilst legal systems that adapt quickly foster financial development (Beck et al., 2003). In this regard, Civil law systems are considered to have more adverse repercussions for financial development than Common law systems.

Application of the latter idea to the origins of the AEO institution itself looks not straightforward because the AEO concept emerged almost simultaneously both in Common law and civil law countries. On the one hand, we may trace AEO origins back to 1980th experiments with developing of Trusted Trader Programs in Sweden and Netherlands that possessed all distinct peculiarities of the contemporary AEO status, including voluntary entrance based on specific criteria, a partnership approach, self-assessment by the company, validation of systems, risk mapping, generous benefits programs, certification (Karlsson, 2017). On the other hand, the roots of WCO approved AEO program typically are traced to the US programs initiated in response to the September 11, 2001, attacks, including Container Security Initiative (CSI), the International Ship and Port Facility Security Code (ISPS) and the CustomsTrade Partnership Against Terrorism (C-TPAT) (Veenstra, 2019) with the primarily focus shifted from theft controls and contraband reductions to securing supply chains to heighten national security (Gupta et al., 2019).

Furthermore, the whole AEO concept and thus the standards for its legal regulations have been at least twice 'blended' at the supranational level. Firstly, such a 'blending' occurred within the WCO frameworks resulting in WCO SAFE Standards of 2005 and evolving in its later revisions. Secondly, it happened within the WTO 
Trade Facilitation Agreement of 2013. Besides, one should consider regional peculiarities, such as the EU AEO regulations.

In aggregate, due to the information provided by the WCO members for 2020, there were identified worldwide:

- 97 operational AEO programs and 20 AEO programs under development.

- 33 operational Customs Compliance programs and 4 Customs Compliance programs due to be launched.

- 87 bi-lateral and 4 plurilateral or regional Mutual Recognition Agreements (MRA) of AEO status concluded and 78 MRAs under negotiation (Compendium of Authorized Economic Operator Programmes, 2020).

Thus, it is possible to speak of a significant number of somewhat different national rules and criteria applicable to AEO. Although they have common roots in international standards, the national characteristics of each country dictate their perception, which often leads to essential distortions of the original ideas. For example, a failure of rule-makers and customs authorities to share the 'trusted trader' concept subsequently leads to different perceptions of AEO's role and functions within the supply chain and the significant differences in respective national legislation (Ostrikova, 2021). Furthermore, national peculiarities can significantly dilute the benefits and simplifications that are supposed to provide business under the status of AEO.

However, the process can also go in the reverse direction. The essential peculiarity of the AEO institution is that it has been derived from general efforts on freeing trade through trade facilitation while ensuring the security of supply chains. According to Frensch, Horvath \& Huber (2021), international trade may impact legal institutions in three primary channels, including overall openness to trade, a specialization on institutionally intensive exports, and a dependence on exports of natural resources, where two first channels help countries to improve the rule of law. Hence, the 
introduction of AEO due to its trade facilitation nature may also be associated with expectations of enhancing the rule of law in related spheres.

\section{AEO as an intersectoral legal institution}

Considering the AEO as a legal institution, one may acknowledge the problem of legal origin and its impact on the national substantive law of different countries. Even though the term itself grounds primarily on legal positivism, at this very point, we can find significant differences both in terminology and in understanding the essence of this phenomenon. According to Ruiter (2001), legal institutions can be roughly characterized as distinct legal systems governing specific forms of social conduct within the overall legal system and their hallmark of legal institutions is that they can be dealt with as independent social phenomena. At the same time, institutional theory of normative order sticks to the representation of normative order as a working system with a particular focus on the processes of norm-creation and on the processes of establishing institutional arrangements (contracts, trusts, and the like) within private and lower-level public law (MacCormick, 1997, p. 1061). At the higher levels, public law can be associated both with the principles of effective and efficient organization of governance and distributive justice, thus concerning empowering institutionsagencies (MacCormick, 2009, p. 191).

At the same time, post-Soviet legal doctrines follow the structure of legislation in this aspect to a greater extent. The institution of an authorized economic operator (AEO) is no exception. Its regulatory framework is primarily viewed as the intersection of financiallegal regulation and administrative-legal regulation. The general theoretical idea of intersectoral legal institutions is that we deal with a system of normative regulations. However, interconnected and, at the same time, relatively separate from each other, that together form a specific part of the legal field and regulate a particular area 
of legal relations (Parkhomenko, 2008, p. 198). Also, an institute of law is described as a set of legal provisions that, due to unique legal means and techniques, regulate homogeneous social relations (Levytska, 2021, p. 2). Despite the numerous definitions of the concept of 'institution of law,' all of them are substantially similar. By generalizing the relevant definitions, the following features of the institution of law can be identified. (1) The law institute forms system-designed provisions structurally grouped into a single regulatory entity. All the institute's rules are logically correlated, distinguishing the institute of law from a disparate normative array. (2) Normative rules that form the institution of law are a relatively autonomous system, making it possible to ensure the regulation of a particular area of social relations. (3) The relations regulated by the law institute are distinguished by species specificity. Thus, there are such types of relations in the field of taxation: relations of tax control, relations of reporting, relations of tax consulting, relations of bringing the taxpayer to financial responsibility, etc.

The intersectoral institutions of law arise on the borders of related legal branches, particularly those characterized by the identity of the circle of social relations regulated by them. Moreover, intersectoral institutes are divided into two types. The "border" institutions of intersectoral nature are formed based on regulations of related legal branches, whereas the 'functional' institutions are formed at the junction of heterogeneous, dissimilar in subject and method of legal regulation branches of law. 'Cross-border' intersectoral institutions impose on the regulation subject of one branch of law the elements of the subject of another related branch. At the same time, 'functional' cross-institutions have different subjects and methods of legal regulation. The single factor that unites the regulatory mechanism of such branches of law is the functional links between the relevant norms. 'Border' intersectoral institutions arise at the junction of related public or private branches of law (e.g., civil and labor law). As for the "functional" intersectoral institutions, they 
are formed based on diverse, public, and private branches of law (e.g., civil and administrative law) (Polenina, 1975, p. 75-77).

If we follow the appropriate approaches of intersectoral law institutions characterization, the institute of AEO is the 'border' intersectoral institution because its regulatory framework is formed by the prescriptions of two related public law branches: financial law and administrative law. These areas of law are: 1) the subject of legal regulation with common characteristics; 2) the similarity of the method of legal regulation.

The concept of administrative law focuses on relations of protective and regulatory nature, having a procedural or substantive nature relating to the implementation of public authorities' rights and responsibilities, administrative and jurisdictional protection (Kurinnyi, 2004, p. 34). The subject of financial law is related to the public authority activities of authorized entities on the accumulation, distribution (redistribution), and further use of public finances (Kucheriavenko, 2016, p. 28). Therefore, we can conclude that a certain similarity characterizes administrative and financial law subjects. Although, there are some specific differences between them. However, the similarity of the subject of legal regulation in terms of management characteristics has a decisive impact on the similarity of administrative and financial law. In administrative law, we must not forget that we are interested in its integrative sub-branch - customs law. The imperative nature also characterizes the legal regulation of AEO because, on the one hand, it relates to the management relations implemented under specific customs procedures, while on the other hand, it relates to the revenue from customs duties.

However, it would be limited to approach the AEO institution merely from the positions of public law. The AEO status, in fact, reflects the internal state of a company, including reliability and commitment to upholding security procedures, proof of the solvency of the company, ability for efficient cooperation in the supply chain 
through timesaving and reduction of bureaucracy, etc. (Laszuk \& Ryciuk, 2016).

Furthermore, if we turn to enhance supply chains security, one should also focus on companies' private rulemaking towards establishing respective internal rules and practices. According (Yang $\&$ Wei, 2013) a, supply chain security management embraces four crucial security management dimensions, including: facility and cargo management; accident prevention and processing; information management; partner relationship management.

All the dimensions mentioned above are primarily the responsibility of companies, whilst state authorities can influence them basically through different policy measures. With that regard, the procedure of obtaining AEO status when authorities evaluate different aspects of supply chain security management is mere the form of external governmental influence upon the formation of private rules and practices.

For example, the initial idea behind AEO that governments delegate primary control responsibilities to the collaborative and trusted businesses themselves, while in return these businesses benefit from trade simplification, includes two crucial shifts in the administrative relations:

- changing in the G2B relationship from the traditional controland-command to a more trust-based relationship;

- replacing the traditional labor-intensive Customs controls with businesses' self-control on Customs issues (den Butter et al., 2012, p. 268).

Such shifts in the government to business relations and delegation of controls will inevitably affect the operation of legal norms in this area. In effect, government-established norms are to some extent replaced by government-recognized private rules and procedures. This recognition mainly means that the internal rules of the AEO generally have the same regulatory effect on compliance with the law as the rules governing traditional customs control procedures. Thus, 
the operation of traditional substantive law becomes dependent on specific company regulations, soft law in the form of standards and best practices.

\section{Methodology of legal regulation of the AEO institution}

Within the post-soviet legal conceptions, much attention is paid to the category of 'method of legal regulation.' Typically, the definition the method of legal regulation is described as a specific way of influencing the norms of the law on a particular group of social relations for their consistent regulation, which consists in approving potentially possible or mandatory algorithms of the behavior of participants in legal relations with the mediation of such normative mechanisms, and in establishing approximate-desired results of interaction of such subjects of legal relations (Gorshenev, 1966, p. 401). Also, a method of legal regulation can be described as a system of legal means, techniques, and methods of regulating social interaction as a whole and its elements (Sorokin, 1976, p. 84).

The AEO institute is also characterized by the prevailing imperative legal regulation method. The rules for obtaining the status of AEO the need for permanent compliance with such criteria is clearly and unambiguously established by law. At the same time, the institute of AEO is characterized, among other things, by some aspects of discretion. The entity decides whether it needs special simplifications and benefits provided by the AEO. In other words, to import or export goods, a resident enterprise does not have to receive AEO-C or AEO-B status. However, this special status as $\mathrm{AEO}$ benefits such an enterprise.

Accordingly, the business entity is objectively interested in such special status and therefore has the right to acquire it at its own will (element of discretion). However, the acquisition of such status will be carried out according to a clearly defined legal procedure and in the case of compliance with statutory conditions (element of imperative). At the same time, this kind of discretion is fully 
realized within the general imperative regulation. Therefore, the entity's behavioral algorithms (whether or not to acquire AEO status) depend on the entity's own will.

In this case, the entity itself cannot determine the procedure for obtaining the appropriate status or adjust in any way the conditions (criteria) for obtaining the status of AEO. The dispositive aspect of the intersectoral institute of AEO has a behavioral character: it concerns the issue of realizing such a subjective right or refraining from its realization.

Another element of discretion in the AEO institution is the possibility for the business entity to choose whether to pass the AEO-C or AEO-B authorization or acquire both statuses. In other words, the resident company independently chooses whether it wants to have one of the relevant statuses and enjoy a set of simplifications and/or benefits provided by such status or receive all benefits and simplifications provided by complex status - legal status AEO-C and AEO-B simultaneously.

Again, as we see, the corresponding element of discretion is behavioral. An entity cannot self-regulate key aspects of AEO status, and it does not have a wide variety of alternatives in terms of eligibility criteria. The subject of power also grants this status by making an appropriate decision. All this together indicates that the elements of discretion in the intersectoral institute of AEO are implemented on the terms and in the order of imperative legal regulation. This allows us to formulate the following characterizing maxim: 'discretion under conditions of imperativeness.'

However, the limitations of the company's discretion in obtaining the AEO status may be viewed more broadly. For example, research of the US companies' motivations to participate in different governmental programs focused on the security of supply chains (primarily the C-TPAT program) revealed that companies experienced tremendous pressures from their operational environment to adopt respective norms and practices. In aggregate, there were four 
primarily environmental drivers motivating companies to adopt supply chain security practices determined, including:

- government coercive based on possible detrimental severe effects for the firm such as direct costs (e.g., longer lead times due to extra inspection in ports of incoming goods) and indirect costs (e.g., losing potential customers as a result of not being certified by the government programs) in the case of non-participating in respective programs;

- customers security expectations by which suppliers (both material and service providers) must comply to retain business and remain competitive;

- competitor pressures due to that security best practices can be developed and copied among a competitive marketplace, which would allow for marketing of SCS to their customers;

- society pressure in the form of companies' reluctance to be involved in a security breach of some kind that may have broad society resonance.

Thus, we have to summarize that the intersectoral institute of AEO is mainly regulated through the imperative legal regulation method. However, at the same time, certain impregnations of discretion (discretion in behavior) are characteristic of the AEO institute.

\section{Conclusions}

The Institute of AEO can be viewed from different theoretical positions, each with its explanatory potential. Turning to the concept of 'legal origins' allows us to explain the differences in the methods and ways of implementing AEA programs in different countries and identify key obstacles to the effective implementation of international standards. In many cases, the AEO implementation process concerns overcoming national legal traditions that do not permit a necessary level of trust and partnership between authorities and companies. The institutional aspect shows the peculiarities of regulating the legal status of the AEO within the framework of the national legal 
system and the complex interaction of public and private law in the implementation of the mission of the AEO to ensure the security of the supply chain. Finally, the analysis of the methodology of legal regulation makes it possible to reveal the ratio of imperative and dispositive aspects in the application of rules and standards when granting AEO status and its further functioning.

\section{REFERENCES}

Beck, T., Demirgüç-Kunt, A., \& Levine, R. (2003). Law and finance: why does legal origin matter? Journal of Comparative Economics, 31, 4, 653-675. https://doi.org/10.1016/j.jce.2003.08.001

Bradford, A., Chang, Y., Chilton, A., \& Garoupa N. (2021). Do Legal Origins Predict Legal Substance? The Journal of Law and Economics, 64, 2. https://doi.org/10.1086/712420

Compendium of Authorized Economic Operator Programmes (2020). World Customs Organization. http://www.wcoomd.org/-/media/wco/public/global/ pdf/topics/facilitation/instruments-and-tools/tools/safe-package/aeocompendium.pdf?la $=$ en

Den Butter, F., Liu, J., \& Tan, Y. (2012). Using IT to engender trust in government-to-business relationships: The Authorized Economic Operator (AEO) as an example. Government Information Quarterly, 29, 261-274 http://dx.doi.org/10.1016/j.giq.2011.05.004

Frensch, R., Horvath, R., \& Huber, S. (2021). Openness effects on the rule of law: Size and patterns of trade. International Review of Law and Economics, 68, December, 106027. https://doi.org/10.1016/j.irle.2021.106027

Gorshenev, V.M. (1966). The concept of the method of legal regulation and its varieties. Scientific works of the Sverdlovsk Law Institute, 5, 388-415. [in Russian].

Gupta, V., Ding, X., \& Testa, T. (2019). A case study of drivers, barriers, and company size associated with C-TPAT program. Supply Chain Forum: An International Journal, 20, 4, 332-347. https://doi.org/10.1080/16258312. 2019.1694387

Karlsson, L. (2017). Back to the future of Customs: A new AEO paradigm will transform the global supply chain for the better. World Customs Journal, 11, $1,23-33$. 
Kucheriavenko, M.P. (Ed.) (2016). Finance law. Pravo. [in Ukrainian].

Kurinnyi, Ye.V. (2004). Subject and object of administrative law of Ukraine. Lira LTD. [in Ukrainian].

La Porta, R., Lopez-de-Silanes, F., \& Shleifer, A. (2008). The Economic Consequences of Legal Origins. Journal of Economic Literature, 46(2), 285-332. https://doi.org/10.1257/jel.46.2.285

Laszuk, M., \& Ryciuk, U. (2016). The Importance of Authorized Economic Operator Institution for the Security of Supply Chain in the International Goods Turnover of Polish Enterprises. Eurasian Journal of Business and Management. https://doi.org/10.15604/ejbm.2016.04.01.004

Levytska, N.O. (2021). Normative-law institute: delimitation with related concepts. Journal of the Academy of Advocacy of Ukraine, 4, 1-5. [in Ukrainian].

MacCormick, N. (2009). Concluding for Institutionalism. In M. Del Mar, \& Z. Bankowsky (Eds.). Law as Institutional Order. (pp. 187-200). Burlington, VT, Ashgate Publishing Company.

MacCormick, N. (1997). Institutional Normative Order: A Conception of Law. Cornell Law Review, 82, 5, Art. 5, 1051-1070. http://scholarship.law.cornell. edu/clr/vol $82 /$ iss $5 / 5$

Ostrikova, T. (2021). AEOs' Institution Development in the EU and Ukraine: Common Standards in Different Perceptions. Lex Portus, 7(5), 69-87. https://doi.org/10.26886/2524-101X.7.5.2021.4

Parkhomenko, N.M. (2008). Sources of law: issues of theory and methodology. [in Ukrainian].

Polenina, S.V. (1975). Complex legal institutions and the formation of new branches of law. Jurisprudence, 3, 71-79. [in Russian].

Ruiter, D.W.P. (2001). Legal Institutions. Legal Institutions. Law and Philosophy Library, 55. Springer, Dordrecht. https://doi.org/10.1007/978-94-015-9765-4_4

Sorokin, V.D. (1976). Method of legal regulation. Theoretical problems. [in Russian].

Tweddle, D. (2008). Logistics, Security and Compliance: The Part to Be Played by Authorised Economic Operators (AEOs) and Data Management. World Customs Journal, 2, 1, 101-105.

Veenstra, A.W. (2019). International Trade, Global Supply Chains and Compliance. In H. Zijm, M. Klumpp, A. Regattieri, S. Heragu (Eds.). Operations, Logistics and Supply Chain Management. Lecture Notes in Logistics. (pp. 131-161). 
Springer, Cham. https://doi.org/10.1007/978-3-319-92447-2_7

Yang, C., \& Wei, H. (2013). The effect of supply chain security management on security performance in container shipping operations, Supply Chain Management, 18, 1, 74-85. https://doi.org/10.1108/13598541311293195

\section{Острікова Т. Правові витоки та міэсгалузеве регулювання інституту} УЕО. - Стаття.

Основні елементи інституту УЕО спочатку виникли у законодавствах різних країн, правові системи яких належать як до сімей загального, так і континентального права. Крім того, була неминучою варіативність вирішуваних завдань: від загальних питань безпеки ланцюжка постачання до акценту на протидії терористичним загрозам. При цьому, сучасні стандарти УЕО формувалися як на рівні міжнародних організацій, таких як Всесвітня митна організація та Світова організація торгівлі, так і на регіональному рівні (наприклад, СС та асоційовані країни). Тому ми стверджуємо, що існує декілька перспективних підходів до аналізу правового статусу УЕО, включаючи концепцію “правового походження” та інституційні правові теорії. Вони мають значний потенціал для пояснення національних відмінностей у реалізації інституту УЕО, специфіки взаємодії норм різних галузей права у регулюванні діяльності УЕО, методів та способів державного управління програмами УЕО. Крім того, у статті розглядається питання міжгалузевого регулювання інституту УЕО, який охоплює норми кількох галузей права публічного (адміністративного, податкового та митного) та приватного. Крім того, ідея делегування компетенції та відповідальності щодо забезпечення безпеки ланцюжків постачань від державних органів приватним особам (тобто “довіреним трейдерам”) створює зсув у правовому регулюванні, коли різні внутрішні правила та практика приватних компаній стають важливими для виконання поставлених завдань, покладених на інститут УЕО.

Ключові слова: УЕО, інститут, митниця, безпека, ланцюжок постачання, правове походження, спрощення процедур торгівлі.

\section{Острикова Т. Правовое происхождение и межстраслевое регулирова-} ние института УЭО. - Статья.

Основные элементы института УЭО изначально возникли в законодательствах разных стран, правовые системы которых относятся как к семьям общего, так и континентального права. Кроме того, была неизбежна вариативность решаемых задач: от общих вопросов безопасности цепочки поставок до акцента на противодействии террористическим угрозам. При этом, современные стандарты УЭО формировались как на уровне 
международных организаций, таких как Всемирная таможенная организация и Всемирная торговая организация, так и на региональном уровне (например, ЕС и ассоциированные страны). Поэтому мы утверждаем, что существует несколько перспективных подходов к анализу правового статуса УЭО, включая концепцию “правового происхождения” и институциональные правовые теории. Они обладают значительным потенциалом для объяснения национальных различий в реализации института УЭО, специфики взаимодействия норм разных отраслей права в регулировании деятельности УЭО, методов и способов государственного управления программами УЭО. Кроме того, в статье рассматривается вопрос межотраслевого регулирования института УЭО, охватывающего нормы нескольких отраслей права - публичного (административного, налогового и таможенного) и частного. Кроме того, идея делегирования компетенции и ответственности относительно обеспечения безопасности цепочек поставок от государственных органов частным лицам (т.е. “доверенным трейдерам”) создает сдвиг в правовом регулировании, когда различные внутренние правила и практика частных компаний становятся важными для выполнения поставленных задач, возложенных на институт УЭО.

Ключевые слова: УЭО, институт, таможня, безопасность, цепочка поставок, правовое происхождение, упрощение процедур торговли. 